\title{
浮葉植物（ガガブタ）群落の栄養塩収支および 日射遮蔽に関する現地調査 A FIELD OBSERVATION ON THE NUTRIENTS BUDGET AND SHELTERING OF SOLAR RADIATION OF A FLOATING-LEAVED PLANT (Nymphoides indica) COMMUNITY
}

\author{
丸山治朗 ${ }^{1} \cdot$ 中井正則 ${ }^{2}$ - 有田正光 ${ }^{2}$ \\ Jiro MARUYAMA, Masanori NAKAI and Masamitsu ARITA \\ 1 学生会員 修 (工) 東京電機大学大学院理工学研究科応用システム工学専攻（†350-0394 埼玉県比企郡鳩山町石坂）
${ }^{2}$ 正会員 工博 東京電機大学教授＼cjkstart理工学部建設環境工学科（†350-0394 埼玉県比企郡鳩山町石坂）
}

\begin{abstract}
A floating-leaved plant (Nymphoides indica) community in an irrigation pond was investigated with respect to absorption and release of nutrients $(\mathrm{N}, \mathrm{P})$ and sheltering of solar radiation. In summer, the plant community grew up absorbing nutrients from the bottom mud, and then, both the values of the biomass and nitrogen content took a peak in July, however, the value of the phosphorus content exhibited a characteristic variation with two peaks both in July and August. In addition, multiplication of phytoplankton was largely suppressed due to sheltering of solar radiation by the floating-leaves in the plant community. In fall, the plant community released nutrients into the water body due to withering, and then, the value of Chl.-a greatly increased in the plant community with a time lag of about a month.
\end{abstract}

Key words : floating-leaved plant, Nymphoides indica, nutrient, biomass, phytoplankton, sheltering of solar radiation

\section{1. はじめに}

生態系における生産者は光合成を行うことによって増 殖しており，各生産者の光合成に対する優位性の差異が 生産者の個体数バランスに大きな影響を与えていると考 えられる.ため池・湖沼などの水域では，生産者として 大型水生植物・植物プランクトン・付着藻類の 3 者がよ く知られているが，一般に大型水生植物（抽水植物・浮 葉植物）が日射吸収の点において優位に立っており，こ のことが多様な生態系の形成に結びついている.

近年, 閉鎖性水域では富栄養化が顕在化しているため, 大型水生植物（抽水植物・浮葉植物）が存在しない場合 には,植物プランクトンが十分な日射と栄養塩を獲得し, 容易に異常増殖する. その結果, 水域の透明度は低下し, 底層に到達する光エネルギーが減少するため, 付着藻類 や沈水植物が衰退する. また，枯死した植物プランクト ンが底層へ大量に沈降することによって急激な貧酸素化 が発生し, 多くの底生生物が死滅するとともに底泥から 栄養塩の溶出が生じ，富栄養化がさらに加速化する.

一方，抽水植物・浮葉植物が生息している水域では， その群落によって日射が吸収されるため, 植物プランク トンの異常増殖が抑制される. 特に, 浮葉植物の場合に
は，水面に展開している浮葉による日射遮蔽効果が顕著 であると考えられる. また，これらの植物は生長に伴っ て水域の栄養塩を吸収するとともに，その植物体自身を 付着藻類の基盤として提供している. このように，抽水 植物・浮葉植物は生産者間の均衡を保ち, 生態系の生物 多様性に貢献するのみならず，水質維持の面においても 大きく寄与している.しかしながら, これらの植物には, 秋季の枯死分解によって栄養塩が植物体中から水中へ回 帰し, 水域の栄養塩濃度を増加させるという負の側面も 存在している.

以上のような, 大型水生植物（抽水植物・浮葉植物） が生態系と水質に与える効果のうち，栄養塩吸収につい ては抽水植物を中心にして既に多数の研究が行われてい $3^{1)-3)}$. しかし, 日射遮蔽に関するものは研究例が少な く, 特に浮葉植物の顕著な日射遮蔽効果についてはほと んど研究がなされていない. この効果は, 植物体の生長 段階によって著しく変化することが予想されるため, 今 後の詳細な調査が必要不可欠である. また，秋季におけ る大型水生植物群落の枯死分解については, 回帰栄養塩 による植物プランクトンの増殖が指摘されているものの, その影響の程度については意見が分かれている $\left.{ }^{3)}-7\right)$.

本研究では, 在来性の浮葉植物であるガガブタ (Nymphides indica) が群落を形成する小規模なため池に 


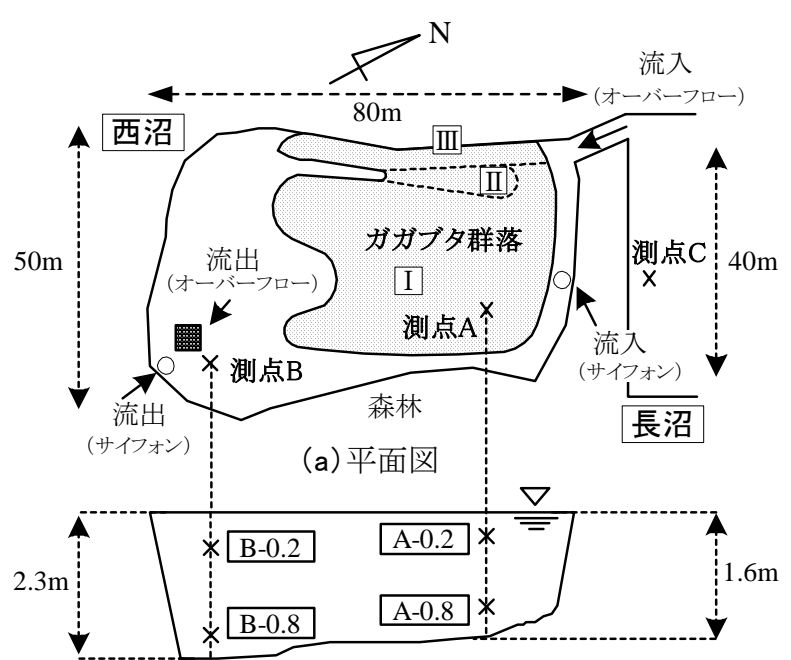

(b) 断面図

I], III, IIII : 領域 I , II , III

図-1 西沼の概要

おいて現地調査を実施し, 浮葉植物群落の栄養塩収支と 日射遮蔽について検討した. 本研究のねらいは，ガガブ 夕群落の栄養塩吸収・回帰特性および植物プランクトン に対する日射遮蔽効果を定量的に評価し，今後の大型水 生植物群落を要とした生態系の維持・管理システムを構 築するうえでの基礎データを提供することである.

\section{2. 現地調査}

調查地点は埼玉県比企郡滑川町の西沼（ため池）であ り, 水深 $2(\mathrm{~m})$ 程度以下の領域にガガブタが群落を形 成している. 西沼は上下 2 段式の灌溉農業用ため池の下 側に当たっており，その上側には長沼（満水時の表面積 約 $\left.6900\left(\mathrm{~m}^{2}\right)\right)$ がある. 西沼の諸元は, 満水時の表面積 $3477\left(\mathrm{~m}^{2}\right)$, 総貯水量約 $5600\left(\mathrm{~m}^{3}\right)$, 最大水深 $3.49(\mathrm{~m})$, 平均水深 $1.58(\mathrm{~m})$ であり, サイフォンとオーバーフロ 一により長沼の池水が西沼へ流入している. (図-1 参照). 調査期間は2004年1月 14日～2004年12月21日であり, 原則として週に 1 回のペースで水質項目の測定を, 月に 2 回のペースでガガブタ群落の調査を行った（ガガブタ 群落の調査期間は, ガガブタが水面に浮葉を展開してい た 2004 年 5 月 11 日〜2004 年 11 月 17 日である).

測定した水質項目は, 水深, 透明度, 水温, DO (溶存 酸素) 濃度, $\mathrm{pH}$ (水素イオン濃度), $\mathrm{EC}$ (電気伝導率), 濁度, $\mathrm{CO}_{2}$ (炭酸ガス) 濃度, Chl.-a (クロロフィル a), $\mathrm{T}-\mathrm{N}$ (全窒素)，T-P (全リン)， $\mathrm{PO}_{4}-\mathrm{P}$ (リン酸態リン) で ある(ただし， T-N，T-P， $\mathrm{PO}_{4}-\mathrm{P}$ の測定は月に 2 回のペ 一スである). 測点は, ガガブタ群落内 (測点 A), ガガ ブタ群落外 (測点 B) および長沼の流出口付近 (測点 C) の 3 点であり, 測点 $\mathrm{A}, \mathrm{B}$ の 2 割・8 割水深および測点 $\mathrm{C}$ の水面下 $20(\mathrm{~cm})$ の位置で直接測定および採水を行った
(図-1 参照)。なお， DO 濃度は, 東亜電波工業㑣製の水 質チェッカ（WQC-22A）を用いて直接測定した。 また, Chl.-a， $\mathrm{PO}_{4}-\mathrm{P}$ の值は，自作の採水ビン $(500(\mathrm{ml}))$ を用 いて採水した試料水をもとに，ターナーデザイン社製の ポータブル蛍光光度計（Aquafluor）と東亜電波工業侏製 の多項目水質計 (LASA 1) を用いてそれぞれ分析した(他 の水質項目については，本論文ではそのデータを使用し ないため, 測定方法を省略する).

ガガブタ群落の測定項目は, 群落の占有面積, 単位面 積当たりの浮葉・茎の現存量 (乾重量), 浮葉・菱の乾重 量に対する $\mathrm{N} \cdot \mathrm{P}$ 含有率であり, 以下にその測定・分析 方法を示す．群落の占有面積は，目測により求めた值に 補正係数（1 回分の精密な測量值と目測值との比）を乗 じて算出した. 単位面積当たりの乾重量については, 次 の方法で算定した，測定日ごとに，まず，浮葉・茎を 8 $\sim 16$ 組採取し, 近似葉面積（中心軸の長さx中心軸上端 の横幅）を測定した後に浮葉・茎の乾重量を測定し, 近 似葉面積と浮葉・茎の乾重量との関係を求めた。 また, 密生度 (単位面積当たりの浮葉・茎の数) を $50(\mathrm{~cm}) \times 50$

(cm) の領域内の浮葉枚数より算出した（1 枚の浮葉に 1 本の茎が対応している. したがって, 浮葉の密生度と 茎の密生度は一致するので, 以下では単に密生度と表現 する). つぎに, 平均近似葉面積 (十数枚の浮葉の平均值) を用いて, 近似葉面積と浮葉・茎の乾重量との関係から それに対する茎 1 本・浮葉 1 枚分の平均乾重量を求め, 密生度を乗じて単位面積当たりの浮葉・茎の乾重量を算 定した. 一方, 浮葉・茎の $\mathrm{N} ・ \mathrm{P}$ 含有率については, 採 取した植物体試料を粉砕し, ヤナコ分析工業侏製の CHN コーダを用いて分析することにより $\mathrm{N}$ 含有率を，また， 植物体試料と精製水を混合し，その試料水を多項目水質 計を用いて分析することにより $\mathrm{P}$ 含有率を算出した.

\section{3. 調査結果と考察}

\section{（1）ガガブタ群落の季節変遷と栄養塩吸収・回帰特性}

本節では，ガガブタ群落の季節変遷に伴う栄養塩吸 収・回帰の特性について検討する.

図-2にガガブタ群落の占有面積の経日変化を示寸 (図 中の領域 I は池中心付近の大きい浮葉が占有する領域, 領域亚は池の端付近の小さい浮葉が占有寸る領域, 領域 II は領域 I，IIIの中間に位置する，浮葉がまばらな領域 である). 同図より, 5/11 からガガブタ群落の占有面積は 領域 I, IIIを中心にして増大し始め, また，5/26〜6/8 に は領域川の面積が大きく増大していることがわかる．さ らに, 6/8 から領域 I の面積が再び大きく増大しており, この頃より池中心付近のガガブタが生長し始めている. 7/20にはガガブタ群落の占有面積（領域 I 〜III）が最大 值 $2297\left(\mathrm{~m}^{2}\right)$ を示しており, 満水時の表面積の $66(\%)$ を占めている. その後, 占有面積はわずかな増減を伴い 


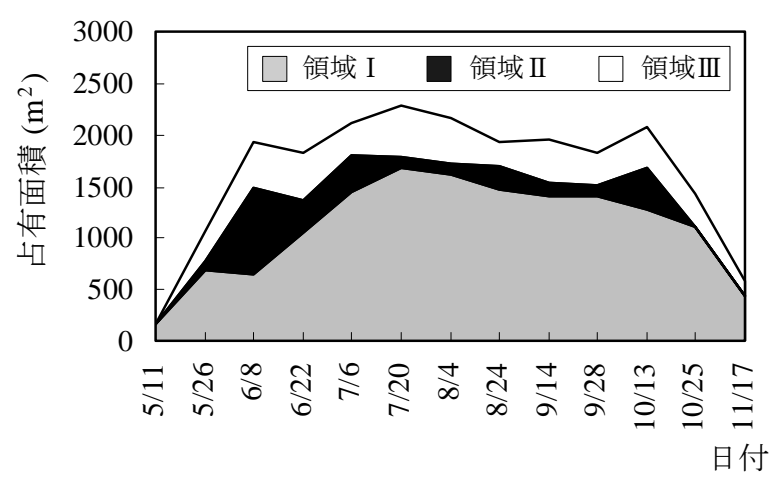

図-2 ガガブタ群落の占有面積の経日変化

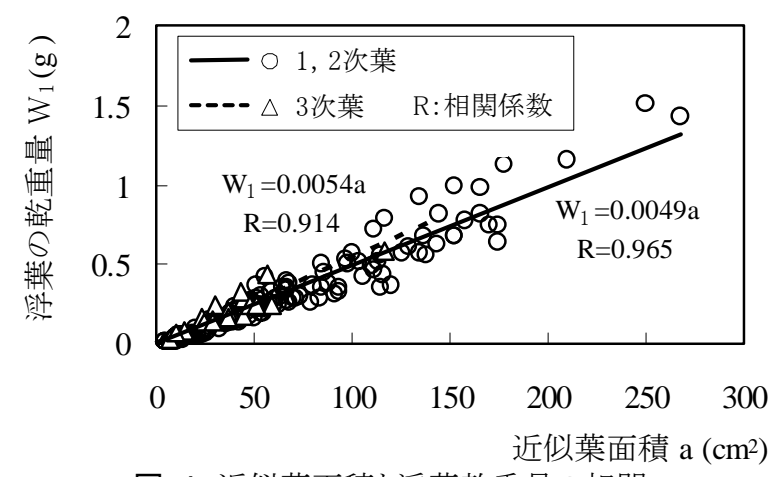

図-4 近似葉面積と浮葉乾重量の相関

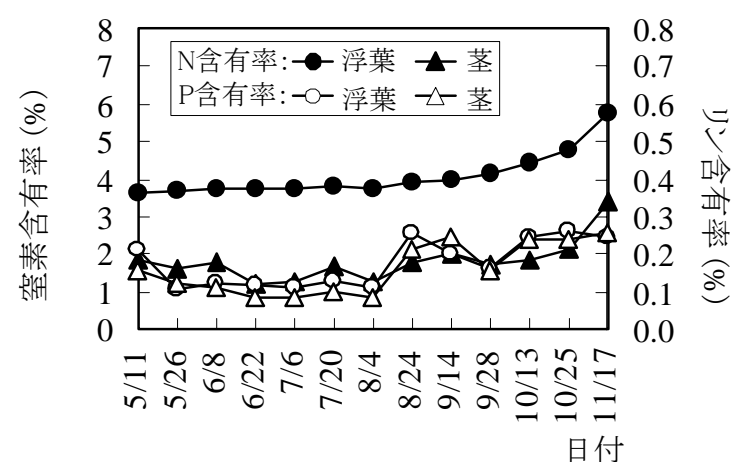

図-6 ガガブタの栄養塩 $(\mathrm{N}, \mathrm{P})$ 含有率の経日変化

ながら，ほぼ一定の值で推移し，10/13 から単調に減少 している.

図-3にガガブタの平均密生度（領域 I， III）の経日変 化を示す (図中の 1 次葉は生長初期に見られる小さい浮 葉, 2 次葉は 1 次葉の枯死後に伸長し, 花芽・殖芽を形 成する浮葉, また, 3 次葉は 2 次葉の殖芽の基部より伸 長する浮葉である ${ }^{8)}$. なお, 領域川は浮葉がまばらなた め, 測定を省略した。 また, 領域IIIでは 3 次葉は確認さ れなかった)。まず，領域 I の結果について検討する. 同 図のように, $1 \cdot 2$ 次葉の平均密生度は 5/11 5/26 に急激 に増大した後，5/26〜6/8 に約 25（\%) 減少している. これは, 5/11〜5/26には多くの1次葉が伸長するものの, 5/26〜6/8 にその 1 次葉が 2 次葉に生え変わる時に枯死す るためであり, 浜島の観察結果 ${ }^{8)}$ とよく一致している. また， $6 / 8$ 以降は $1 \cdot 2$ 次葉の平均密生度が再び増大傾向 を示しており，2 次葉が 6 月上旬より本格的に生長して いることがわかる。 しかし，7/6〜7/20には1・2 次葉の
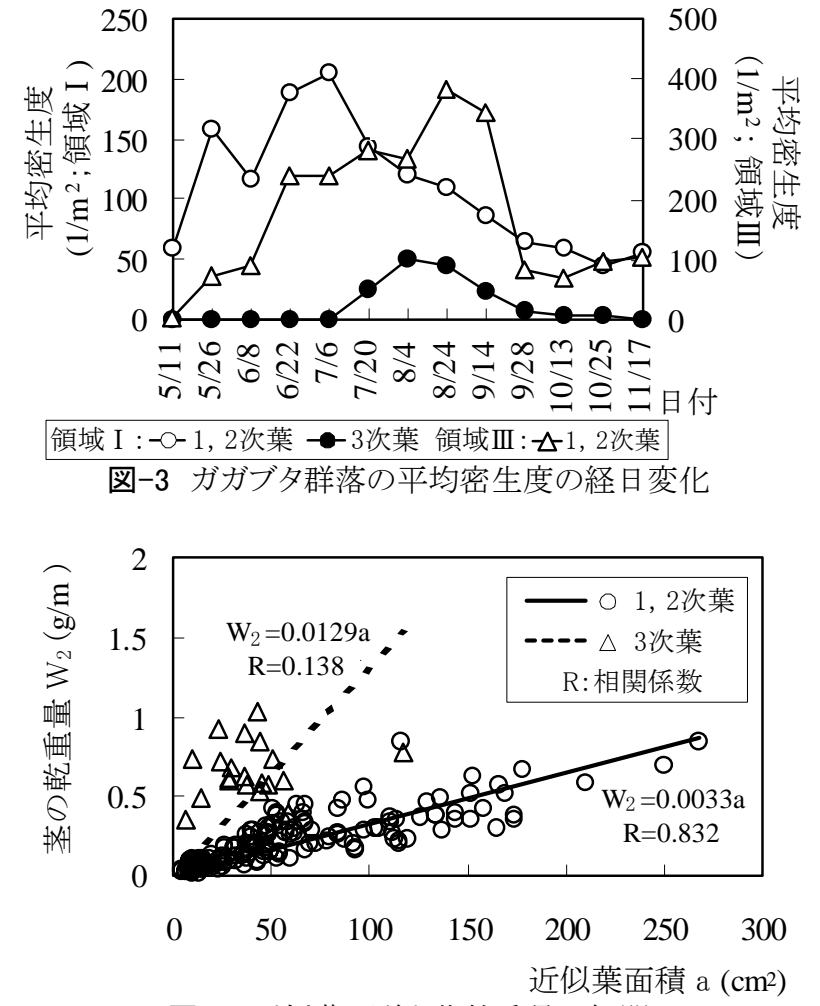

図-5 近似葉面積と茎乾重量の相関

平均密生度が減少し，3 次葉のそれが増大している.こ れは, 3 次葉の伸長に伴って古い 2 次葉が徐々に枯死し たためであり，この時期より 2 次葉の枯死が観察され始 めた. その後も, 3 次葉の平均密生度はしばらくの間 (7/20 ～8/4）増大し続けるが， $8 / 4$ 以降は $1 \cdot 2$ 次葉， 3 次葉と もに平均密生度がほぼ単調に減少している，つぎに，領 域吕におけるガガブタの平均密生度を見ると，1・2 次葉 のそれは 6/8〜8/24 の約 2 力月半にわたってほぼ単調に 増大していることがわかる（特に，6/8～6/22，8/4〜8/24 の増大は急激である)。一方，8/24 以降は平均密生度が 一気に減少している.

図-4, 5 に $1 \cdot 2$ 次葉, 3 次葉における浮葉の乾重量と 近似葉面積の関係，および茎の乾重量と近似葉面積の関 係を示す (図中には最小二乗法によって求めた直線が挿 入してある. なお，茎の乾重量は単位長さ $(1 \mathrm{~m})$ 当たり の重量で表している). 図-4よりわかるように，1・2 次 葉，3 次葉ともに近似葉面積と浮葉の乾重量は良好に相 関しており，ほぼ比例関係にある（その比例係数は両者 でほぼ同一の值となっている)。また，図-5 より，1・2 次葉の近似葉面積と茎の乾重量も良好に相関しており, 乾重量の大きい茎（太い茎）には面積の大きい浮葉がつ いていることがわかる. 一方，3 次葉については，デー タがかなりばらついている（ただし，3 次葉は最大でも 全浮葉の約 $30 （ \%)$ を占めるにすぎず，また，その茥の 長さが短いため，群落の乾重量に与える影響は $2 （ \%)$ 以下である).

図-6 はガガブタの植物体について, 部位ごとの $\mathrm{N}$ 含有 率，P含有率の経日変化を示したものである．浮葉の 


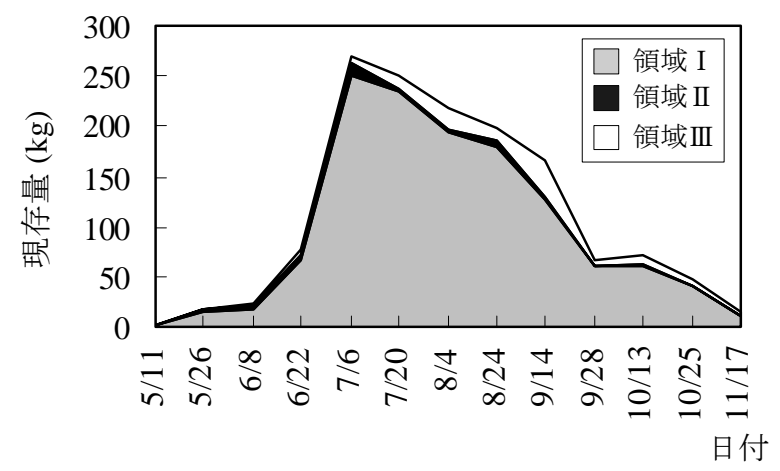

図-7 ガガブタ群落の現存量の経日変化

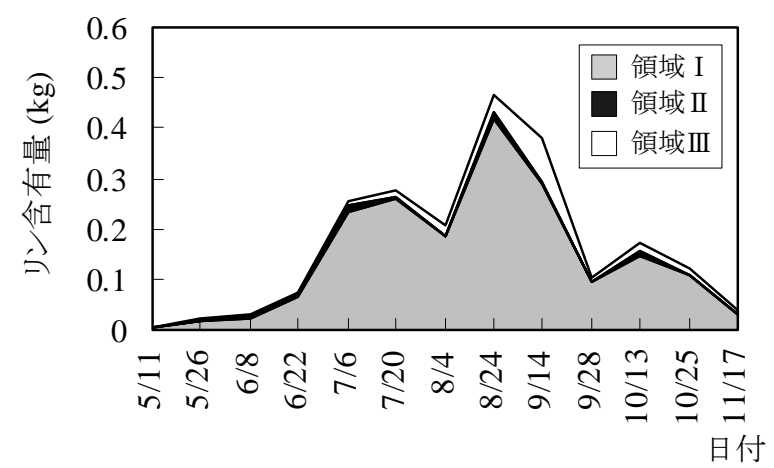

図-9 ガガブタ群落のリン $(\mathrm{P})$ 含有量の経日変化

$\mathrm{N}$ 含有率は, 全測定期間を通じて茎のそれの 2 倍強程度 となっている. これは, 光合成器官である浮葉にクロロ フィル a $\left(\mathrm{C}_{55} \mathrm{H}_{72} \mathrm{~N}_{4} \mathrm{O}_{5} \mathrm{Mg}\right)$ など, $\mathrm{N}$ を含んだ物質が多く 存在しているためである.これに対して，P 含有率は全 測定期間を通じて浮葉・茎でほぼ同一の值を示している. また, $\mathrm{N} ・ \mathrm{P}$ 含有率の季節変動については以下のようで ある. 図-6 より， $\mathrm{N} ・ \mathrm{P}$ ともに $8 / 4$ を境に含有率が上昇 していることがわかる. しかし， $\mathrm{N}$ 含有率の上昇が緩や かであるのに対し, $\mathrm{P}$ 含有率のそれは 8/4〜8/24 に急激に 生じている (浮葉: $0.11 \rightarrow 0.26(\%)$, 茎: $0.08 \rightarrow 0.21(\%)$ ). これは, 底層が嫌気的環境になるに従って底泥に吸着し ていたリン酸態リン $\left(\mathrm{PO}_{4}-\mathrm{P}\right)$ が遊離し, ガガブタの根が それを吸収するためと推察される. 実際に，8/24には底 層の DO 濃度が $0.78(\mathrm{mg} / \mathrm{l})$ とかなり低い值を示してお り(嫌気的環境にあり), そこでの $\mathrm{PO}_{4}-\mathrm{P}$ 濃度は 0.027 $(\mathrm{mg} / \mathrm{l})$ と比較的高かったことが確認されている.

図-7 - 9にガガブタ群落の現存量(乾重量), $\mathrm{N}$ 含有量, $\mathrm{P}$ 含有量の経日変化を示寸 (この 3 者については, 単位 面積当たりの浮葉・茎の乾重量, 浮葉・茎の $\mathrm{N} \cdot \mathrm{P}$ 含有 率，群落の占有面積をもとに算出した). 図-7 よりわか るように，群落の現存量は領域 I の占有面積の増大と同 調して 6/8 より増大し，6/22７/6の 2 週間で最大值 270 (kg) まで一気に到達している. その後, 現存量は減少 し始め，9/28には7/6のそれの約 25（\%) となっている (なお, 領域 I の現存量の減少は 8/24 より激しくなって いる)。つぎに, ガガブタ群落の $\mathrm{N} ・ \mathrm{P}$ 含有量について検 討寸る. 図-8 より, $\mathrm{N}$ 含有量は現存量のそれとほぼ同様 の傾向で増減しており, やはり, 8/24 以降急激に減少し

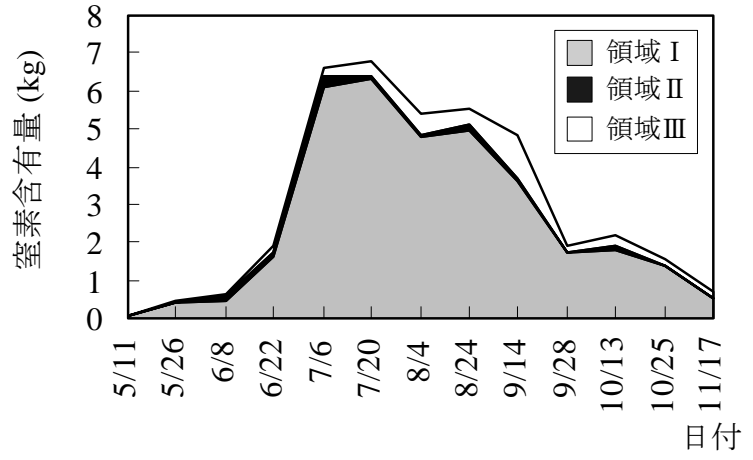

図-8 ガガブタ群落の窒素 $(\mathrm{N})$ 含有量の経日変化

ている.これは，ガガブタの植物体の $\mathrm{N}$ 含有率が全測定 期間にわたって大きな変化がなく, $8 / 4$ 以降の上昇も緩 やかであるためと考えられる (図-6 参照)。これに対し て, P 含有量は $8 / 4$ までは現存量・ $\mathrm{N}$ 含有量とほぼ同様 の傾向を示寸ものの，8/4〜8/24 に急激に増大し，8/24 に は最大值 $0.47(\mathrm{~kg})$ に達している (図-9 参照)。これは 前述のように，この時期がガガブタの植物体の $\mathrm{P}$ 含有率 が急激に上昇した時期に当たっており，その影響を強く 受けているからである (図-6 参照)。また，8/24 以降の $\mathrm{P}$ 含有量の減少は現存量, $\mathrm{N}$ 含有量のそれと比較して特 に激しい. 以上の結果を総合して判断すると，8/24 頃よ り本格的な枯死分解が始まっており, それに伴って大量 の栄養塩が池水中へ回帰したと考えられる. なお, 本格 的な枯死分解以前（7/6 8/24）の現存量の減少は, 役目

(殖芽・三次葉の生産) を終えた一部の二次葉の枯死が 原因である (茎はその後も残存しており, 本格的な植物 体の枯死は始まっていない).

\section{（2）ガガブタ群落による日射遮蔽と植物プランクトンの 動態}

本節では, ガガブタの浮葉による日射遮蔽効果が植物 プランクトンの動態に与える影響を検討する. ここで, ガガブタ群落の日射遮蔽効果を表す指標として, 被覆率 (平均密生度 $\left(1 / \mathrm{m}^{2}\right) \times$ 平均近似葉面積 $\left.\left(\mathrm{m}^{2}\right) \times 100(\%)\right)$ を用いる（密生度が高くなる時期（被覆率で70（\%) 程 度以上）には浮葉同士が重なり合うため，その時の実質 の被覆率はここで示寸数值より小さく, 概ねその $0.6 〜$ 0.9 倍である).

図-10 に表層における Chl.-a の経日変化をガガブタ群 落の被覆率との関係において示寸 (図中の A-0.2, B-0.2 はそれぞれ測点A, B の2 割水深を表している). 最初に, 被覆率の経日変化とガガブタ群落の占有面積のそれ（図 -2 参照）を比較する. 図-2, 10 より, ガガブタ群落の占 有面積は 5/11〜 6/8 に大きく増大寸るのに対し, 被覆率は 緩やかな増大に留まっていることがわかる。 これは，ガ ガブタが生長初期に群落全体にわたって 1 次葉を展開す るため, 占有面積は一気に拡大寸るものの, 1 次葉の葉 面積が非常に小さいためにその影響が被覆率にあまり反 映されないことを示している，一方，枯死分解が本格的 


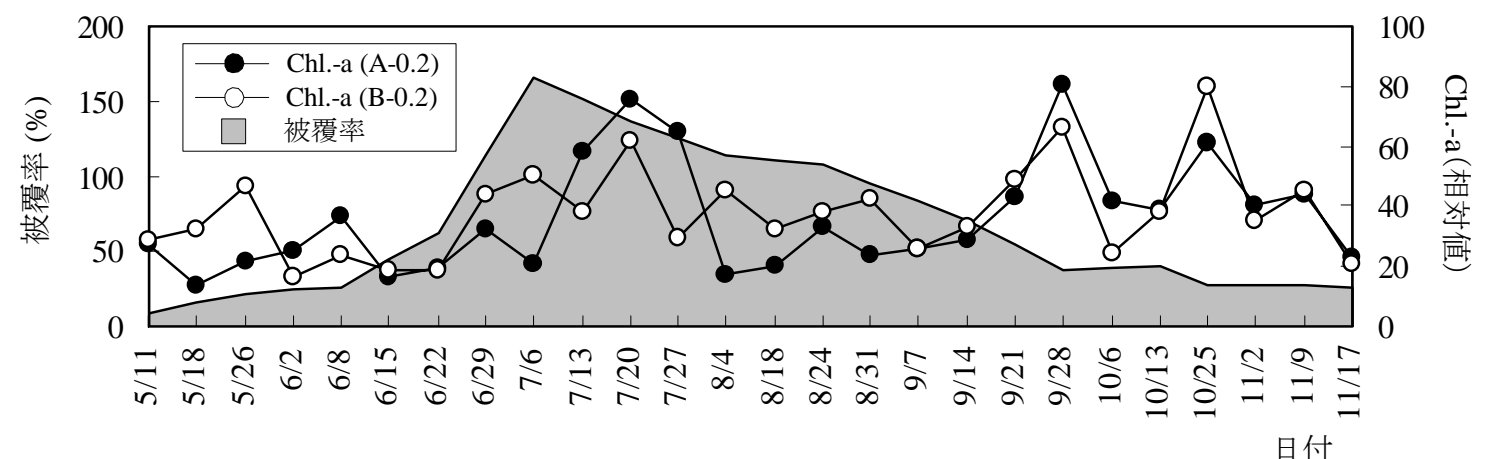

図-10 ガガブタ群落の被覆率とChl.-a(表層)の経日変化

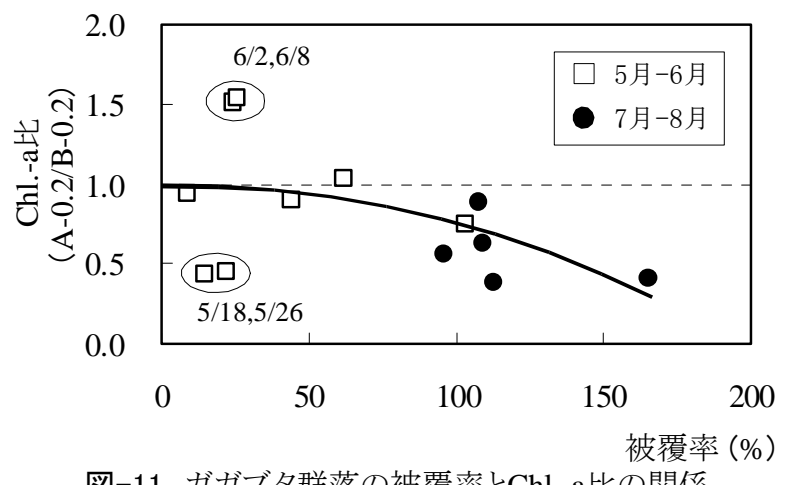

図-11 ガガブタ群落の被覆率とChl.-a比の関係

に始まった後の約 1 カ月間（8/24～9/28）については, 被覆率が急激に減少するのに対し, 占有面積は最盛期と ほぼ同様な值を保っている，これは，ガガブタの枯死分 解が群落全体にわたつて緩やかに進行するため，その影 響が占有面積にはあまり表れず，密生度にのみ顕著に表 れるからである (図-3 参照).

以下では，図-10 をもとにして，被覆率の季節変動が 表層の植物プランクトンの動態に与える影響を検討寸る. 最初に，ガガブタの生長期である 5/11〜 7/6 に注目する. 5/11〜6/22 については, 両測点（A-0.2, B-0.2）のChl.-a はかなり変動するものの, 全体としてほぼ同程度の值を 示している. したがって，この期間においては，ガガブ 夕群落の日射遮蔽による植物プランクトンの抑制効果は あまり表れていないと言える。これは，群落の占有面積 が拡大しているものの (図-2 参照), 被覆率が 9〜62 (\%) と低いため, 十分な量の日射が群落内の表層へ入射した からと考えられる. なお， 5/18，5/26 の B-0.2 における Chl.-a の高い值は測点 B $の$ 底層が貧酸素化し, 底泥から 栄養塩の供給があったことが原因と推察される. 測定デ 一タによれば，5/11，5/18，5/26 における測点 B の底層 (8 割水深) の DO 濃度は 0.90, 0.82, 5.18 (mg/l) であ り，5/26 にやや増大するものの， 2 週間程度にわたって 嫌気的環境が続いており， $\mathrm{PO}_{4}-\mathrm{P}$ が溶出していた可能性 が高い（ただし，実際の $\mathrm{PO}_{4}-\mathrm{P}$ 濃度は植物プランクトン 増殖後のため, ほぼ 0 (mg/l) であった)。

その後, 被覆率は 6/22～7/6 に急激に増大し，7/6には 最大值 $165 （ \%)$ を示している. 両測点の Chl.-a はとも に 6/22〜6/29 に増大するが, B-0.2 の増大はA-0.2 のそれ
より顕著である.さらに，6/29〜7/6 には B-0.2 の Chl.-a が増大するのに対し，A-0.2 のそれは減少しており，被 覆率の増大に伴って両測点の Chl.-a の差が広がっている. これは，この期間にガガブタ群落の被覆率が急激に増大 したため, 群落内の表層へ入射する日射が浮葉によって 遮蔽され，A-0.2 では植物プランクトンの増殖が大きく 抑制されたからである ${ }^{7), 9)}$. 7/6〜8/24 はガガブタ群落の 最盛期である (図-2 参照). 図-10では, 被覆率が 7/6に 最大值を示した後に緩やかな減少傾向を示しているもの の，どの測定日においても $100 （ \%)$ 以上の高い值を保 っている. この時期の Chl.-a の值は，(7/13〜 7/27 を除い て）A-0.2 のそれが B-0.2 のそれを下回っており，ガガブ 夕群落の日射遮蔽に基づく植物プランクトンの抑制効果 が顕著に表れている. なお, 7/13〜7/27 においてはChl.-a の逆転現象（A-0.2 の值が B-0.2 のそれよりも高い）が生 じている. これは，西沼の流入源である長沼でアオコが 発生したため, 大量の植物プランクトンが西沼へ流入し, ガガブタの茥や浮葉に接触することにより群落内に帯留 した影響と考えられる（長沼・西沼は灌溉用水として使 用されているため, 一時的な大量流出・流入がある).

前述のように，8/24 からガガブタの枯死分解が始まっ ており, 被覆率は8/24 9/28 に単調に減少している（図 -10 参照). 同時期の Chl.-a の変動を見ると， 8/31 までは A-0.2 より B-0.2 の方が高い值を示しているが，9/7, 9/14 には両測点でほぼ同じ值となっている. また, 9/14〜9/28 には両測点ともに Chl.-a が増大傾向を示しており, 最終 的にA-0.2の值がB-0.2のそれを上回っている.このA-0.2 における高い值は，ガガブタの枯死分解によって栄養塩 が水中へ回帰すること，浮葉の減少（被覆率の低下）に 伴って群落内の表層へ入射する日射量が増大することの 2 つの原因によって, A- 0.2 で植物プランクトンの増殖が 活発になったためと考えられる. ただし，この時の両者

(被覆率と A-0.2 の Chl.-a) の変動を詳しく見ると, 8/24 にガガブタ群落の被覆率が低下した後, 1 力月程度の夕 イムラグを伴って 9/21にA-0.2 で植物プランクトンの激 しい増殖が起きていることがわかる (なお, この時, B-0.2 においても同時に植物プランクトンの増殖が見られるが, これはガガブタの枯死分解に伴う回帰栄養塩が移流と拡 散によって測点 B へ輸送されたためと推察される). 
このように, ガガブタ群落の被覆率の低下と植物プラ ンクトンの増殖に時間差が生じる理由として, つぎの 2 点が考えられる. 第 1 に，ガガブタの枯死分解が始まっ た直後の 8/24～9/14 においては，被覆率の低下が緩やか であるため, ガガブタ群落は依然として日射遮蔽効果を 維持しており，植物プランクトンが十分な量の日射を利 用できなかったことである. 実際に，8/24～9/14 におけ る被覆率は108（\%）から $71 （ \%)$ 一減少しているもの の, 比較的高い值を示しており，この時期は群落による 日射遮蔽効果が継続していたことが確認できる.第 2 に, ガガブタ起源のデトリタスの分解速度が小さいことであ る. 一般に，大型水生植物起源のデトリタスは数十日か かって植物プランクトンが利用可能な溶存無機態へ分解 されることが知られている 10)，11).西沼においては，ガ ガブタの枯死分解が始まった $8 / 24$ から植物プランクト ンの増殖が確認された 9/21 までの約 1 カ月間に, ガガブ 夕の植物体に含まれている易分解性物質が溶存無機栄養 塩まで分解されたと推察される.

最後に，ガガブタ群落の日射遮蔽による植物プランク トンの抑制効果を定量的に評価する. 図-11 にガガブタ の生長期〜最盛期（5 月～8 月）における群落の被覆率と Chl.-a 比 (A-0.2 と B-0.2 の Chl.-a の比) の関係を示す (被 覆率の欠測日については，前後の測定日の值を用いて補 間することによってその值を算出した. また，前述のよ うに，7/13〜 7/27 のデータは特殊なケースと考えられる ので，ここでは削除した）。同図より，被覆率が 50 （\%) 程度以下の範囲では Chl.-a 比がほぼ 1 を示しており, 群 落による日射遮蔽効果がほとんどないことがわかる. そ れに対して，被覆率が $90 （ \%)$ 程度を超える範囲では Chl.-a 比が 0.38〜0.88 を示しており, ガガブタ群落の日 射遮蔽による植物プランクトンの抑制効果が顕著に表わ れている. なお，5/18，5/26 および $6 / 2 ， 6 / 8$ のデータは 実線(ベストフィットライン)より大きくずれているが, 前者については前述のように, 測点 B で底層の貧酸素化 に伴う底泥からの栄養塩の溶出があり, これによって B-0.2 における Chl.-a が増大したことが原因である. 後者 については原因が不明であるが，この場合には日射以外 の要因が両測点の植物プランクトン量を支配していると 思われる.

\section{4. まとめ}

本研究では，光合成に対して優位である大型水生植物 に注目し，その一種である浮葉植物（ガガブタ）が群落 を形成する小規模なため池において詳細な現地調査を実 施した. 以下に, 本研究より得られた主要な知見を示す.

1）ガガブタ群落は6月上旬より生長し始め，6月下旬〜

7 月上旬に一気に生長を遂げるとともに, 栄養塩を大
量に吸収する. 群落の $\mathrm{N} ・ \mathrm{P}$ 含有量については, $\mathrm{N}$ が 群落の現存量とほぼ同様の傾向で推移し，7月にピー クを示すのに対し，P 2 つのピーク（7，8月）を 持つ特異な特性を示す.

2）ガガブタ群落は 9 月以降, 枯死分解によって栄養塩を 放出するが, ガガブタ起源のデトリタスが溶存無機栄 養塩一分解されるには数十日かかるため, 植物プラン クトンは枯死分解から約 1 カ月のタイムラグを持っ て増殖する.

3）ガガブタ群落の被覆率が 50 （\%) 程度以下の時期に ついては, その日射遮蔽効果が弱く, 植物プランクト ンの増殖はほとんど抑制されない. しかし, 被覆率が $90(\%)$ 程度以上になると, 日射遮蔽効果が強く発揮 され, 植物プランクトンの増殖は大きく抑制される.

謝辞 : 本研究の一部は東京電機大学総合研究所研究費に より行われたものであり，ここに謝意を表します.

\section{参考文献}

1）桜井善雄 : 水辺の緑化による水質浄化，公害と対策，第 24 巻, pp.899-909, 1988.

2）宗宮功：自然の浄化機構, pp.134-148, 技報堂出版, 1990 .

3）岩熊敏夫, 土谷岳令 : 生育期のヒシによる湖水からの栄養塩 除去の実験的研究, 国立公害研究所研究報告, 第 96 号, pp.101-125, 1986.

4）小林節子, 岩木晃三 : 印旛沼の水草の衰退と水質への影響, 水草研究会会報, 第63 号, pp.11-20, 1998.

5）立本英機, 栗原真理, 小泉利明, 相川正美, 生嶋功 : 西印旛 沼における浮葉植物, オニビシ群落内外の水質の比較, 水環 境学会誌, 第 18 巻, 第 10 号, pp.803-807, 1995.

6）中井正則, 丸山治朗, 有田正光 : 浮葉植物（ガガブタ）が繁 茂するため池の現地調査, 水工学論文集, 第 48 巻, pp.1339-1344, 2004.

7）村田知也, 丸山治朗, 中井正則, 有田正光 : 浮葉植物（ガガ ブタ)が繁茂するため池における生態系と水質およびその季 節変遷に関する現地調查, 水工学論文集, 第 49 巻, pp.1267-1272, 2005.

8）浜島繁隆: ガガブタの観察 おもに生活環と形態, 水草研究 会会報，第22 号, pp.2-4, 1985.

9）生嶋功：水界植物群落の物質生産 I, pp.55-56, 共立出版, 1972.

10）桜井善雄，国土交通省霞ヶ浦河川事務所 : 霞ヶ浦の水生植 物 - 1972 1993. 変遷の記録, pp.234-237, 信山社サイテッ ク, 2004 .

11）松本史郎：鳥屋野潟（新潟市）の水質および堆積物に及ぼ す高等水生植物の影響, 水草研究会会報, 第 27 号, pp.2-15, 1987.

(2005. 9. 30 受付) 